\title{
東日本大震災後ゆりあげ港朝市の早期再建に関わる外的要因と施策の研究 - 類似沿岸商業施設の事業比較と朝市の津波避難事情について - \\ A STUDY ON EXTERNAL FACTORS AND MEASURES RELATED TO THE EARLY RECONSTRUCTION OF YURIAGE WHARF MORNING MARKET AFTER THE GREAT EAST JAPAN EARTHQUAKE
}

- Project comparison of similar coastal commercial facilities and tsunami evacuation in the morning market -

\author{
日詰博文*1, 永野 聡*2, 山田俊亮*3
}

\section{Hirofumi HIZUME, Satoshi NAGANO and Shunsuke YAMADA}

\begin{abstract}
This study examines the external factors involved in the early reconstruction of the Yuriage Wharf Morning Market (YWMM) and the measures taken by the union to respond to these external factors. This case exists in a risky location, but with the consensus of the business, the government and the users, it was the earliest commercial facility to be rebuilt in its original location before the disaster. This project was on the same level as the one before the disaster, and it was also an attempt to create a place to contribute to society.
\end{abstract}

Keywords: Evacuation countermeasures, External factor, Morning market, Disaster hazard area, Tsunami 避難対策, 外的要因, 朝市, 災害仜険区域, 津波

\section{1. 研究背景と目的}

ゆりあげ港朝市[以降、朝市]は宮城県名取市閖上地区に位置し東 日本大震災から被災 3 週間後に暫定的再開、2012 年に仮設で現地 開催、2013 年に本設で現地再建と、ゆりあげ港朝市協同組合[以降、 組合]による民主導の復興を実現した。1）竣工後、再建場所は 2013 年 12 月災害危険区域注 1 に名取市により指定されている。

筆者らは既往研究 ${ }^{1)}$ で朝市の活動に焦点を当て、段階的な資金調 達、他地域、団体との連携を含む行動力、参加型復興の場としての 価值を明らかにした。既往研究 ${ }^{1)}$ は朝市(商業施設)がもたらす地域 貢献を明らかにする目的に対し、本研究は早期現地再建に導いた要 因、活動を支えた要因を明らかにすることを目的としている。既往 研究 ${ }^{1)}$ は内的要因として組合の総会資料と朝市施設の再建過程を基 に分析を行った。一方、本研究は外的要因として再建時期、立地、 建設資金を分析項目としている。また、既往研究 ${ }^{1)} ゙$ で朝市が災害 危険区域内の再建事例である点を強調している。本研究は朝市が震 災後に最も早期に行政による開発事業の完成を待たずして現地再建 した商業施設であることに着目し、現地で早期再建し甚大な被災地 内にも関わらず運営を継続できた要因を明らかにする。そのような 先行事例が存在しないことからも新規性と資料性がある。

\section{2. 既往研究と研究方法 \\ 2-1. 用語の定義}

早期再建に関わる要因を内的要因と外的要因に分類し進める。「内 的要因」は朝市内の出来事や組合の取組が発端となった内発的、自
立的要因とし、「外的要因」は朝市外の存在(地域や空間)や組合外 の他者(行政、団体)が発端となった外発的、他律的要因と位置付け る。時間や規制も外的要因と捉える。避難のための施設は「避難の ための広場と建物を備えた施設で避難生活を送るための場所」であ る指定避難所と、水害などを避けるために一時的に避難する場所」 である津波緊急避難場所［以降、避難場所］を基に進める。注2) 津波 避難タワー、津波避難階段等の津波避難施設も「一時的に避難する 場所」との位置付けから、避難場所として扱う。その上で「指定避 難所、避難場所をまとめる用語」として避難空間を採用する。

\section{2-2. 既往研究と位置づけ}

東日本大震災に関連する商業の研究は他用途と比べると少ない。 商店街再建の研究 ${ }^{2)}$ では、再建まで長期化することで足並みをそろ えることの難しさと、商業者らによってある一定の空間を持つ土地 利用を示すことは被災地区の復興の先導役としての商店街再建の意 義を指摘している。災害危険区域の研究 ${ }^{3)}$ では、災害危険区域の指 定を行う際、指定後の土地利用、空間形成に対する影響が生じるこ とを考慮する必要性を指摘している。災害危険区域指定前、震災直 後の規制の研究 ${ }^{4)}$ では建築基準法 84 条の指定基準として名取市は 被災区域十制度型と分類され、面的整備事業の障害防止を目的と記 している。朝市再建は、84 条解除、被災市街地復興推進地域の解除 (2013 年 3 月)から災害危険区域追加指定前(2013 年 12 月)に実施さ れ、施設が指定による影響を受けず土地利活用を行った事例であり

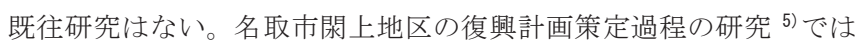
計画策定過程を詳細に整理し、災害危険区域面積の増加により利活

\footnotetext{
*1 針生承一建築研究所 修士(建築学)

*2 立命館大学産業社会学部 准教授・博士 (建築学)

*3 安田女子大学家政学部造形デザイン学科 助教・修士 (工学)
}

Shoichi Haryu Architect and Associates, M.Arch.

Assoc. Prof., College of Social Sciences, Ritsumeikan University, Dr.Arch.

Assist. Prof., Faculty of Human Ecology, Yasuda Women's Univ., M.Eng. 
用未定地区が広がることを指摘している。復興まちづくりにおける 組織体の研究 ${ }^{6)}$ では復興に重要なまちづくり会社の組成プロセスの 有効な手法を明らかにしているが、災害危険区域内の土地活用事例 の研究はない。災害寄付の研究 ${ }^{7)}$ では、日本赤十字社や中央共同募 金会は過半を都道府県、市町村へ分配し、配分にも時間を要し、地 域ニーズに対応することが難しいと指摘されている。筆者らのファ イナンスの研究 ${ }^{8}$ はあるが、他の再建事例に関わる寄付決定までの 過程に着目した研究はない。津波避難の研究は、住民の主体的な津 波避難の研究 ${ }^{9)}$ や、名取市の被災時避難行動の研究 ${ }^{10)}$ 等、当時の避 難行動の研究が多く、再建施設での避難意識や避難対策に着目した ものはない。以上より、本研究は類似沿岸商業施設の事業比較と朝 市の津波避難事情から、早期再建に関わる外的要因に着目し分析を 行う。

\section{2-3. 研究方法}

研究フローFig.1より、3 章で早期再建に関わる外的要因に対する 組合が行った施策を明らかにするために、外的要因の分析項目、再 建時期、立地、建設資金について、東日本大震災後 [以降、震災後] の類似沿岸商業施設と事業比較を行う。外的要因の分析項目ついて の相互関係を Fig.2、(1)〜 (5)に想定される検討項目を基に示す。注3) 検討項目は「立地」に起因寸るものが多く、本体施設再建や自己資 金での避難施設建設では「建設資金」の所在が課題となる。「立地」 と「建設資金」の選択により「再建時期」は左右される。再建が滞 る可能性が多く存在する中、朝市は早期再建を実現しており、外的 要因に対し解決した施策が存在するものと考えられる。

「再建時期」は、オープンまでの経緯を公共事業や避難対策を確認 し類型化、「立地」は、地盤高、災害危険区域との関係、役場や海と

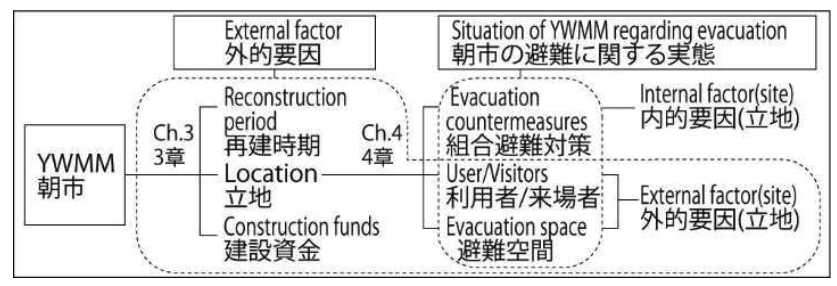

Fig. 1 Flow of research

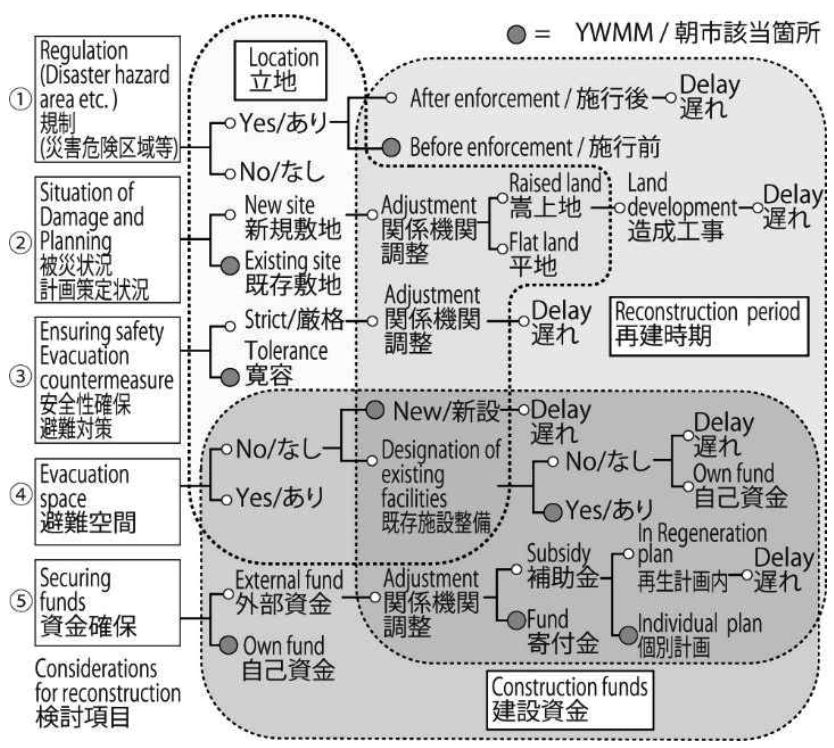

Fig. 2 Interrelationship of external factors
の距離を基に比較、「建設資金」は、工事費、補助金の出先を確認す る。朝市再建の契機となる寄付金受託に至る経緯をまとめ、その背 景を観光統計概要から考察する。Fig.1より、4 章で朝市の津波避難 事情を明らかにするため、内的要因である組合の避難対策を整理し、 立地に関連する利用者と避難空間について考察を行う。Fig. 3 に示 寸再建初期の調查・アンケートを基に分析を行う。注 4) 避難対策に ついて Table 1 のアンケートをプレオープン時に組合員から 1 度、 現地再建後に朝市の来場者に 4 度行った。避難空間については朝市 の再建当初から、新設避難場所が確保されるまでの変遷をまとめる。

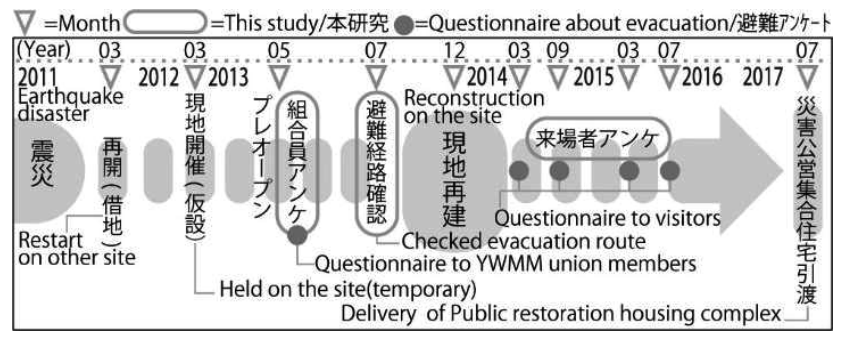

Fig. 3 Flow of reconstruction and the survey

Table 1 Contents of the questionnaire item (Evacuation measures, 2013 2015)

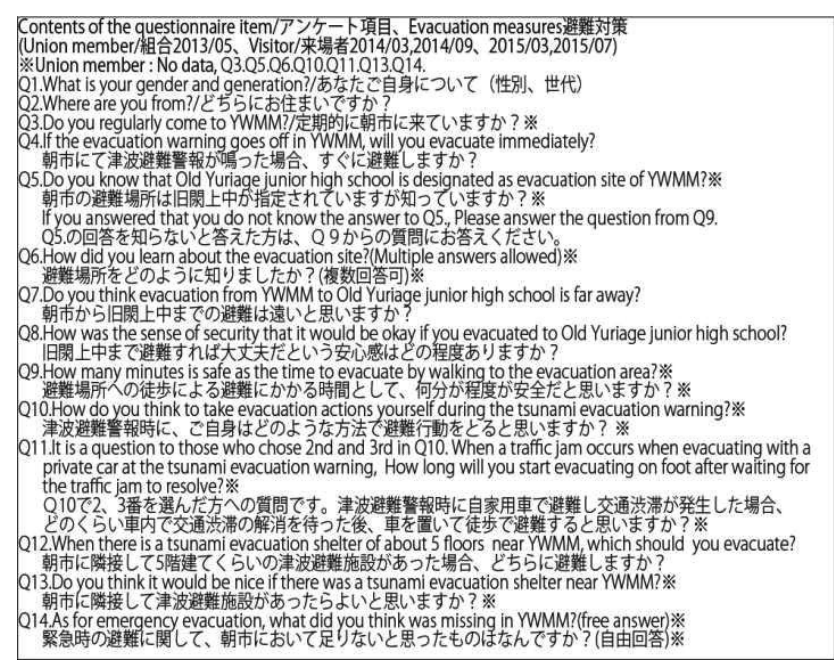

3. 類似沿岸商業施設の事業比較

再建に関わる外的要因の分析項目として、再建時期、立地、建設 資金について震災後建設された類似沿岸商業施設の事業比較を行う。 3-1. 再建時期

震災後の類似沿岸商業施設を行政開発事業、避難所の状況、オー プン時期を類型化し、Table 2のように立地優位型、開発従属型、施 設先行型の再建に分類した。「立地優位型」は高台が避難所として 存在し、行政による開発事業後の再建、「開発従属型」は再建前に 開発事業が行われ、他の新築施設が避難所指定された後の再建、「施 設先行型」は、再建が先行され開発事業後に新築施設の避難所指定 が行われた再建とした。朝市は施設先行型であり、再建時期がプレ オープン 2013 年 5 月と、次に再建が早かった施設と比較しても2年以 上前に先行し再建に至っており、東日本大震災後の沿岸商業施設再 建としては最も早期に再建した事例であることが分かった。

\section{3-2. 立地}

Table 3に各沿岸商業施設の概要を、Table 4に災害危険区域内外 に立地する施設数をまとめた。災害危険区域内に再建が 3 施設あ 
Table 2 Time line and type of rebuilt commercial facilities

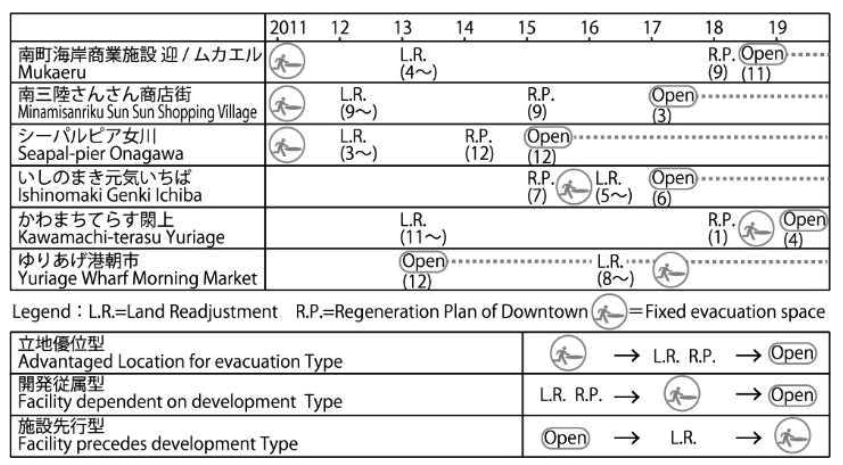

り、災害危険区域内でも再建は行われた。3施設のうち設計津波水 位L1より高い位置 $(\mathrm{L} 1<\mathrm{H})$ での再建が2施設で、 $\mathrm{L} 1$ より低い位置に再 建している施設は朝市のみであった。災害危険区域外に再建した施 設3件は、L1より低い位置(L1>H)に再建しているが、災害危険区域 外のため安全と考えられる。災害危険区域内かつL1より高い位置 $(\mathrm{L} 1<\mathrm{H})$ の 2 施設とも、後背地に避難場所としての高台が存在するの に対し、朝市は近隣に高台もなく比較施設と比べ、立地は危険性の 高い場所だと分かった。合わせて、被災時の中枢となる役場との距 離は名取市内の朝市を含む 2 施設は $5 \mathrm{~km}$ 以上あり徒歩圏外であった。
有無を日本財団注5) の復興支援寄付金状況から確認した。日本財団の 活動記録 ${ }^{11}$ によると、Table 5 のように震災後3年間で商業施設への 寄付金の活用は無く、2011年、2012年に福祉施設や産業施設(水産) と緊急性の高い用途に活用され、2013年に集会施設のようなコミュ ニティに関わる施設に活用された。被災直後に商業施設への寄付金 が活用されづらいのは緊急性の度合いのほか、仮設商店街が建設さ れ一時の猶予があり、土地区画整理事業等の開発事業により建築許 可までに時間を要することが起因した。次に朝市が再建に至った経 緯を寄付金取得の流れから確認寸る。

Table 5 Fund to the facility reconstruction project 2011-13

\begin{tabular}{|c|c|c|c|}
\hline 年度/Year & 2011 & 2012 & 2013 \\
\hline 支出/Expenses ( ( ) & $5,861,451,503$ & $4,806,080,741$ & $4,519,518,327$ \\
\hline $\begin{array}{l}\text { 施設垔建プロジェクト } \\
\text { Facilty reconstruction }\end{array}$ & $\begin{array}{l}5 / 87 \text { 事業(project) } \\
(5.7 \%)\end{array}$ & $\begin{array}{l}5 / 83 \text { 事業(project) } \\
(6.0 \%)\end{array}$ & $\begin{array}{l}11 / 87 \text { 事業(project) } \\
(12.6 \%)\end{array}$ \\
\hline & $\begin{array}{l}\text { 福被施設/Welfare } \\
\text { 紊年援施設/Child }\end{array}$ & \begin{tabular}{|ll} 
産業施設/Industry & (3) \\
施設/Culture & (1)
\end{tabular} & 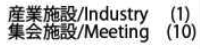 \\
\hline 小計/Subtotal & $\begin{array}{l}535726,400 \\
(2012 / 3 / 31)\end{array} \quad(9.1 \%)$ & $\begin{array}{ll}237,000,000 & (4.9 \%) \\
(2013 / 3 / 31)\end{array}$ & $\begin{array}{l}\begin{array}{l}2,357,460,000 \\
(2014 / 3 / 31)\end{array} \quad(52.1 \%) \\
\end{array}$ \\
\hline
\end{tabular}

\section{3-4. カナダ寄付金取得までの流れ}

カナダー東北復興プロジェクトーは、「コミュニティの再生と未来 のために」との理念の下、震災で失われた公共施設などを再建する 事業支援が行われ、Table 6のように4施設が建設された。支援者の 一団であるブリティッシュコロンビア州は名取市と長年にわたり国

Table 3 Outline of rebuilt commercial facilities near the sea

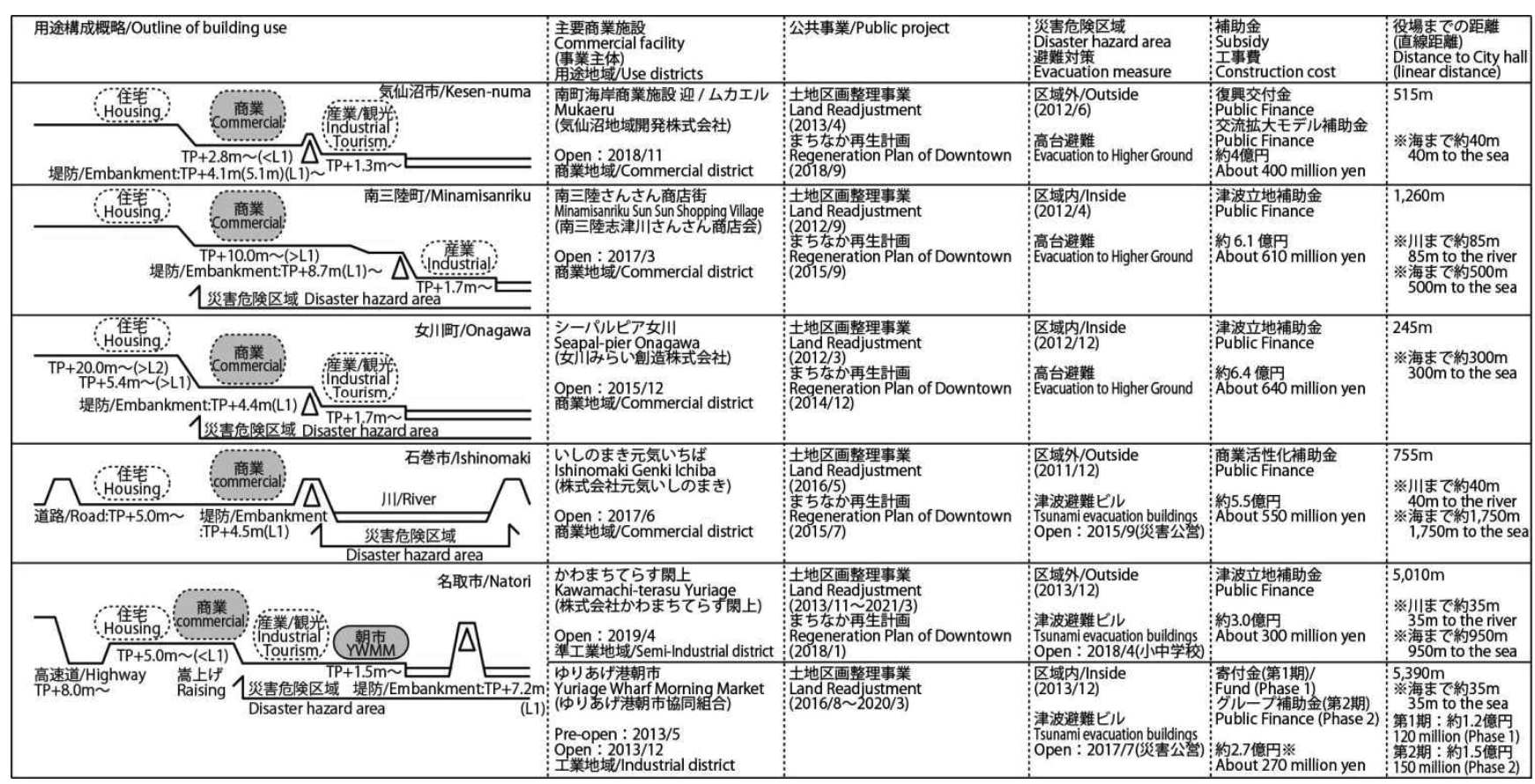

Table 4 Location of the commercial facilities near the sea

\begin{tabular}{|l|c|c|}
\hline & $\mathrm{L} 1>\mathrm{H}$ & $\mathrm{L} 1<\mathrm{H}$ \\
\hline 災害危除区域 内/In Disaster hazard area & 1 & 2 \\
\hline 灾害危険区域 外/ Out Disaster hazard area & 3 & 0 \\
\hline
\end{tabular}

\section{3-3. 建設資金}

Table 3の補助金の項目より、建設資金は国の補助金を活用してお り、朝市も 2 期工事はグループ補助金を活用していた。1期工事時は 寄付金を受けていた。2011年11月に公表された寄付金「カナダ-東 北復興プロジェクト」に 2012 年 5 月に採択調印を行い、朝市再建に 至った。震災後1年 2 カ月で寄付金により本設の再建を行った事例の
Table 6 Fund of the Canada Tohoku Reconstruction Project

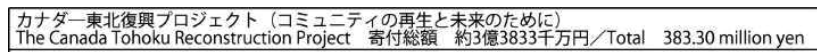
Funders: The Goverment of Canada, British Columbia, Alberta, Forest industry in Canada Coordinator: Canada Wood Group

\begin{tabular}{|c|c|c|c|c|c|}
\hline $\begin{array}{l}\text { プロジェクト名 } \\
\text { Project }\end{array}$ & $\begin{array}{l}\text { coliti } \\
\text { Completed }\end{array}$ & 佣途 & 立地 & 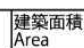 & 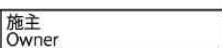 \\
\hline 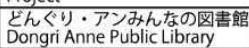 & $\begin{array}{l}2013 / 01 \\
2018 \text { closed }\end{array}$ & \begin{tabular}{|l}
$\mid$ 甾館 \\
Library
\end{tabular} & \begin{tabular}{|l} 
多取市 \\
Natori
\end{tabular} & $238 \mathrm{~m}^{\prime}$ & 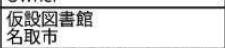 \\
\hline 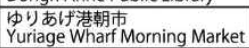 & $2013 / 03$ & 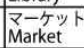 & \begin{tabular}{|l} 
多取市 \\
Natori
\end{tabular} & $778 \mathrm{~m}^{3}$ & 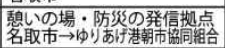 \\
\hline $\begin{array}{l}\text { オランタ 多島ハウス } \\
\text { Oranda House }\end{array}$ & $2014 / 04$ & $\begin{array}{l}\text { 集章 } \\
\text { Chidren }\end{array}$ & 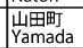 & $198 \mathrm{~m}^{\prime}$ & 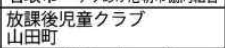 \\
\hline 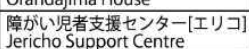 & 12015/01 & 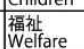 & 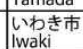 & $473 \mathrm{~m}^{2}$ & 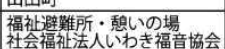 \\
\hline
\end{tabular}

支援息歇/Purpose of support

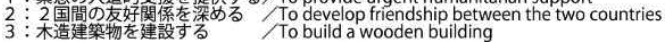


際交流を行っており、林産業界のカナダウッドグループがカナダ材 を使っている地元建設業者へ応募を呼びかけ、地元建設業者が名取 市に相談し朝市を応募対象とする運びとなった。応募時、マーケッ 卜の既存用途に頽いの場、防災の発信拠点という新しい用途を社会 貢献につながる要素を付加し申請していた。また組合と地元設計者 が被災直後から朝市現地再建計画を検討中であったため、地元建設 業者と協同し迅速に応募手続、設計が進んだ。

\section{3-5. 行政における朝市の認知度について}

朝市の認知度について宮城県観光統計概要によると、朝市は主要 観光地点別観光客入込数が、景観 - 名所 ・ 旧跡 ・博物館等に分類さ れ、Fig.4のように2018年で394,500人/年を記録していた。2005年 から宮城県は朝市を観光統計概要に記載されている。2008年から 10 年間の推移をみると、被苂直後 2012 年は 156,605 人/年に落ち込むも のの、2013年に 321,000 人/年とその後2018年にかけて微増し、被災 地観光の短期的な流入ではなく持続的な観光客入込数と判断できる。 2018年の都道府県の観光統計概要で朝市施設を記載した都道府県

はTable 7より、6施設のみであり全国にある朝市施設は主要観光地 としては捉えられていない傾向にある中、宮城県では朝市が観光資 源として継続的に記録され認知されていた。

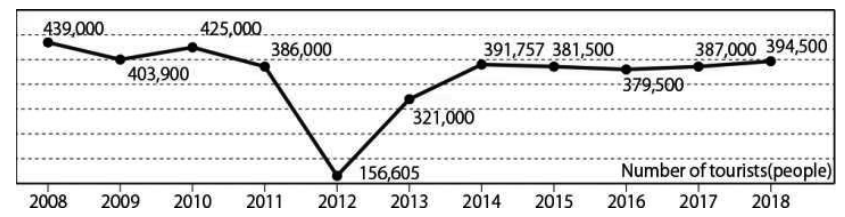

Fig. 4 Number of tourists per year in YWMM

Table 7 Morning market as a major tour ist dest ination in overview of tourism statistics

\begin{tabular}{|c|c|c|c|}
\hline \multicolumn{4}{|c|}{ 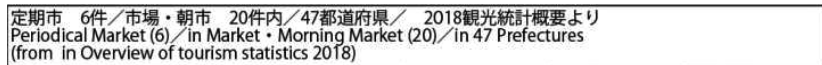 } \\
\hline \begin{tabular}{|l|} 
施設名 \\
Project
\end{tabular} & $\begin{array}{l}\text { 県 } \\
\text { Prefectures }\end{array}$ & \begin{tabular}{|l} 
筧光客数 \\
Tourists(people)
\end{tabular} & \begin{tabular}{|l} 
営業熊 \\
Business style
\end{tabular} \\
\hline $\begin{array}{l}\text { の人じ活き活き常夜燈市 } \\
\text { Noheji Market }\end{array}$ & $\begin{array}{l}\text { 青森県 } \\
\text { Aomori }\end{array}$ & 40,888 & $\begin{array}{l}\text { 定期市 } \\
\text { periodical }\end{array}$ \\
\hline $\begin{array}{l}\text { फりあげ港朝市 } \\
\text { Yuriage Wharf Morning Market }\end{array}$ & $\begin{array}{l}\text { 宮城 } \\
\text { Miyagi }\end{array}$ & 394,500 & $\begin{array}{l}\text { 定期市 } \\
\text { periodical }\end{array}$ \\
\hline $\begin{array}{l}\text { 滕浦朝市 } \\
\text { Katsura Morning Market }\end{array}$ & $\begin{array}{l}\text { 千葉 } \\
\text { Chiba }\end{array}$ & 130,000 & $\begin{array}{l}\text { 定期市 } \\
\text { periodical }\end{array}$ \\
\hline $\begin{array}{l}\text { 大原漁港「港の朝市」 } \\
\text { Ohara Wharf Morning Market }\end{array}$ & $\begin{array}{l}\text { 千葉 } \\
\text { Chiba }\end{array}$ & 90,000 & $\begin{array}{l}\text { 定期市 } \\
\text { periodical }\end{array}$ \\
\hline \begin{tabular}{|l|} 
小田原市「港の朝市」 \\
Odding Market
\end{tabular} & $\begin{array}{l}\text { 神奈川 } \\
\text { Kanagawa }\end{array}$ & 1,000 & 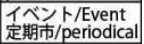 \\
\hline $\begin{array}{l}\text { 六.十朝市 } \\
6 \text { and } 0 \text { Morning Market }\end{array}$ & Nigata & 155,430 & \begin{tabular}{|l|} 
1ベント/Event \\
定期市/periodical
\end{tabular} \\
\hline
\end{tabular}

\section{3-6. 小結}

再建時期は、規制を受ける時期を避け、都市計画法第5 53 条第 1 項 許可のみで短期間に建設され、震災後の沿岸商業施設再建としては 最も早期に再建された事例である。立地は、災害危険区域内かつ L 1 より低い土地に現地再建し、役場は徒歩圈外にあり徒歩の避難場 所としての想定は難しかった。施設先行型の再建であり開発事業後 に近隣の新築施設が最終的に避難場所指定され、それまで避難空間 は万全ではなかった。建設資金は、緊急性の高い用途として扱われ づらい商業施設だが、寄付者の意向による使用目的が明確な寄付金 の獲得が大きな契機となり早期再建に至った。行政や支援者と交流 があり、双方の仲介者間も協力関係があった。その上、組合と地元 設計者が震災後早期に再建検討を始めていたことで急な応募にも迅 速に対応可能であった。民間施設である朝市は震災前より観光資源 として認知度も高く、再建後も震災前相当の観光客を確保している。
早期再建に関わる外的要因をまとめると、再建時期、建設資金、 寄付に関わる支援者については恵まれた条件下で、それら条件を最 大限活用できたのは、先行して再建検討を進めていたことがあげら れる。施設の認知度もあり震災直後から朝市開催するなど活動的な 組合に行政や市民の理解もあったことも後押しとなっている。

立地については現地再建を優先したことにより、類似事業と比較 しても災害危険区域内かつ設計津波水位L1以下の土地であり安全 とは言い切れない。役場からも徒歩圈外で、新設の避難場所を確保 までも時間を要した。土地区画整理事業による嵩上げや道路整備、 災害公営住宅再建後、災害公営集合住宅を避難場所に指定予定のた め、2017年7月迄の約4年を待つ必要があった。組合での自己負担に よる建設も検討を行っていたが、寄付金も受託できず建設資金のめ ども立たなかった。外的要因による避難施設建設を後押しする動き はなく、組合は避難空間をどう確保するかが課題であった。4章よ り再建初期の津波避難事情について考察を行い、立地に関する外的 要因として利用者と避難空間がもたらす影響を考察する。

\section{4. 朝市の津波避難事情について}

朝市の津波避難事情を明らかにするため、避難対策、利用者、避 難空間を項目とした。内的要因である組合の避難対策を整理し、立 地に関連する外的要因である利用者と避難空間について考察を行う。 組合の避難対策を再建当初の組合の緊急時対応マニュアルより把握 し、2013年時の避難経路の確認を行った。利用者属性と避難意識を 明らかにするため、現地再建以降、旧䦥上中を避難場所として一番 長く指定していた 3 年間(2013〜2015年)に朝市内にてTable 1 のア ンケート（組合1回、来場者4回）を行った。朝市の避難空間を明ら かにするため、行政資料と現地調查を基に各避難空間の位置と概要 をまとめる。名取市は隣接する仙台市や岩沼市のような津波避難夕 ワー等の整備は行っていない。被災により、多くの建物が全壊した ため注6)、沿岸に避難空間となる施設は限られており、平野部におい て避難空間をいかに確保してきたかを考察する。

\section{4-1. 組合の避難対策について}

2013 年 6 月朝市は緊急時対応マニュアルを作成しており、当該 マニュアルより地震・津波発生時の対策を確認した。避難計画は、 (1)震度 4 以上の場合、防災ラジオ、インターネットで情報を収集、 (2)津波警報発令を確認し来場者に対してアナウンス、(3)来場者の誘 導開始 : スタッフ率先避難者として避難を開始。5 分以内に屋外 誘導。バス、車の場合は名取市役所へ、徒歩の場合は旧闒上中へ誘 導。(4)施設を閉館、施錠し避難となっていた。平時の避難対策とし て、(1)駐車は海を背にして停車し避難時はすぐ避難できるようにす る、(2)防災無線を兼齐たラジオを常時設置し放送する、(3)施設内に 避難誘導看板、注意喚起マークの貼付、(4)避難誘導備品、防災グッ ズの完備、(5)避難場所案内板を会場内に設置、があげられていた。

組合は現地再建に先立ち、組合を中心に避難訓練を実施し避難経 路の確保に努めた。Fig.5 に施設からの避難経路を示す。災害危険 区域外の被災した旧䦥上中学校[以降、旧䦥上中]が避難場所であり、 朝市から慰霊碑注 7)を横切り、日和山注 8) で左折し西へと続く県道が 避難経路となっている。2013 年末の現地再建までに避難案内板が設 置された。旧閖上中までの避難距離は実測より $1.5 \mathrm{~km}$ であった。 Photo 1 のように 2013〜2015 年に組合で定期的に避難訓練を行っ 
ており、旧閖上中までの避難は徒歩により 2013 年 5 月の記録によ ると約 24.9 分(被験者 18/23 名) と、県目安の避難速度注 9) 超過す る記録時間であった。2015 年 12 月に旧閍上中が解体工事着工後は 仙台東部道路の避難階段を対象に避難訓練を行った。

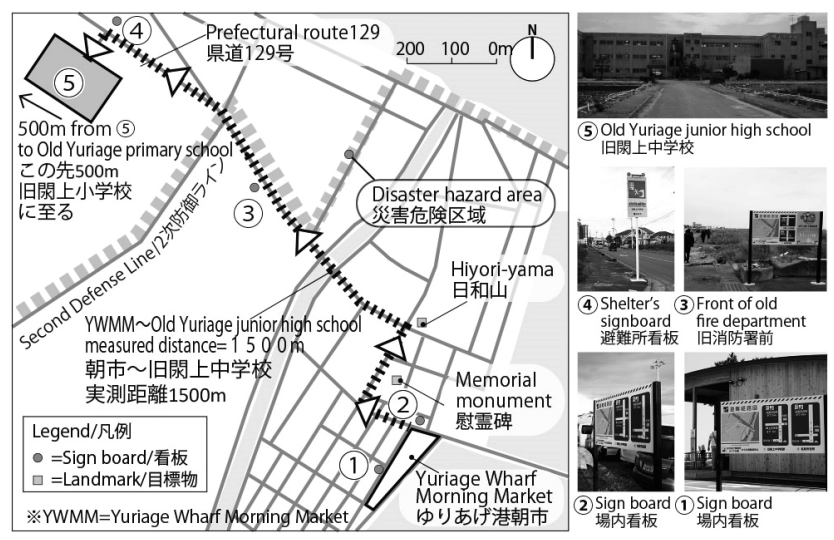

Fig. 5 Evacuation route from YWMM

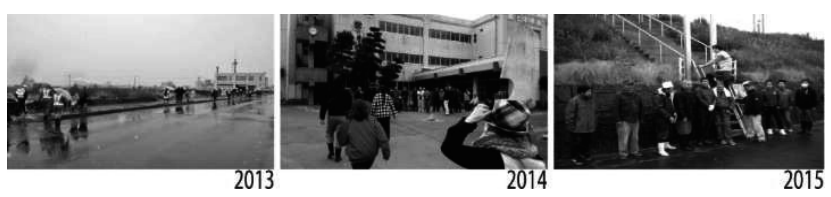

Photo 1 Evacuation dri II by YWMM union members $(2013,2014,2015)$

以上より、組合は被災経験をもとに避難対策を立案し、平時にも 非常時に迅速に対応に移れるよう配慮が見受けられた。旧䦥上中ま での距離、避難時間とも県の目安を超過する結果となっていた。被 災した廃校を避難所とせざるを得なかったが、避難看板の設置、避 難対策、訓練と出来ることを万全に行う組合の取組実態が分かった。

\section{4-2. 利用者の属性について}

朝市利用者アンケートから利用者の属性を考察する。Fig.6、Q1 より [20 代] $9 \%$ 、[30 代] $16 \%$ 、[40 代] $25 \%$ となり、利用者の世代は 20 代以下の若年層の利用は少なく、30 代以上が多いことがわかっ た。既往研究 ${ }^{1)}$ より 2013 年、朝市来場者は $94.4 \%$ が自動車を利用 しており、20 代以下の利用者は、ファミリー層の子連れと考えられ る。Q2より、利用者の居住地は、[仙台市] $37 \%$ 、[名取市] $14.5 \%$ 、[県 外] $35.5 \%$ となり、現地名取市より、仙台市からの来場者が多いこと が分かった。県外からの利用者も多いのは被災後、メディアにより 認知されたことが影響した。最多である仙台市からの利用者にとっ て朝市は、移動時間 30〜60 分程のマイクロツーリズムに通じる観 光地といえる。利用者の来場頻度は、[月数回] $29 \%$ 、[年数回] $20 \%$ 、 [はじめて] $43 \%$ となった。月数回の利用者は定期利用者と考えられ、 年数回の利用者はイベントや季節に合わせ来場する観光客であり、 初めての利用者は被災地観光がきっかけの来場と考えられる。利用 者属性から多層な利用者が混在し、多彩な集客可能性を確認した。

\section{4-3. 利用者の避難意識について}

朝市利用者アンケートから利用者の避難意識を考察する。Fig.6、 Q5 より、避難場所の認知について、[知っている] $39 \%$ 、[知らな い $59.5 \%$ 之、過半が知らないと回答した。被災地に赴く利用者の感 情として能動的に避難対策について調べるものと思われたが、避難 場所を知らないまま来場している利用者の存在を確認した。Q5 で [知っている] と回答の内、Q8 の場所の安心感は、[大変不安、不安]
計 $52 \%$ 、[安心、大変安心]計 $12 \%$ 、[どちらともいえない] $32 \%$ とな った。不安を抱えながらも来場しており、利用者個々の判断により、 沿岸施設であっても客足が途絶えないことが分かった。Q6 より、 避難場所の認知手段は[案内板] $37 \%$ 、[避難訓練] $29 \%$ 、[人づて $] 15 \%$ となった。インターネットでの周知は遅れていたが、現地、イベン ト、ロコミと伝播手段は多岐にわたった。Q10より、避難手段とし て [徒歩で避難場所] $48.5 \%$ 、[車で山手側(仙台東部道路方面)] $35 \%$ 、 [車で避難場所] $5 \%$ となった。9 $90 \%$ 以上を占める自動車来場者も徒歩 での避難を選択したことが分かった。2017 年の名取市によると原則 は徒歩としているが、2013 年朝市地内の案内板には自動車での避難 経路として掲載された。避難方法に罰則は存在せず利用者の判断、 事業者の誘導に任されている。Q13 より、朝市に隣接避難場所設置 の希望は、[必ず必要]40\%、[あった方がよい] $45 \%$ 、[なくてもよい] $9 \%$ となり、避難場所を望む声は多かった。以上より、利用者の避難意 識は震災から数年は経っているが、過剩な不安感は見受けられなか った。寛容な避難意識が利用者の朝市来場を後押しし、現地再建当 初から朝市来場者数を震災前相当の集客につながっていた。

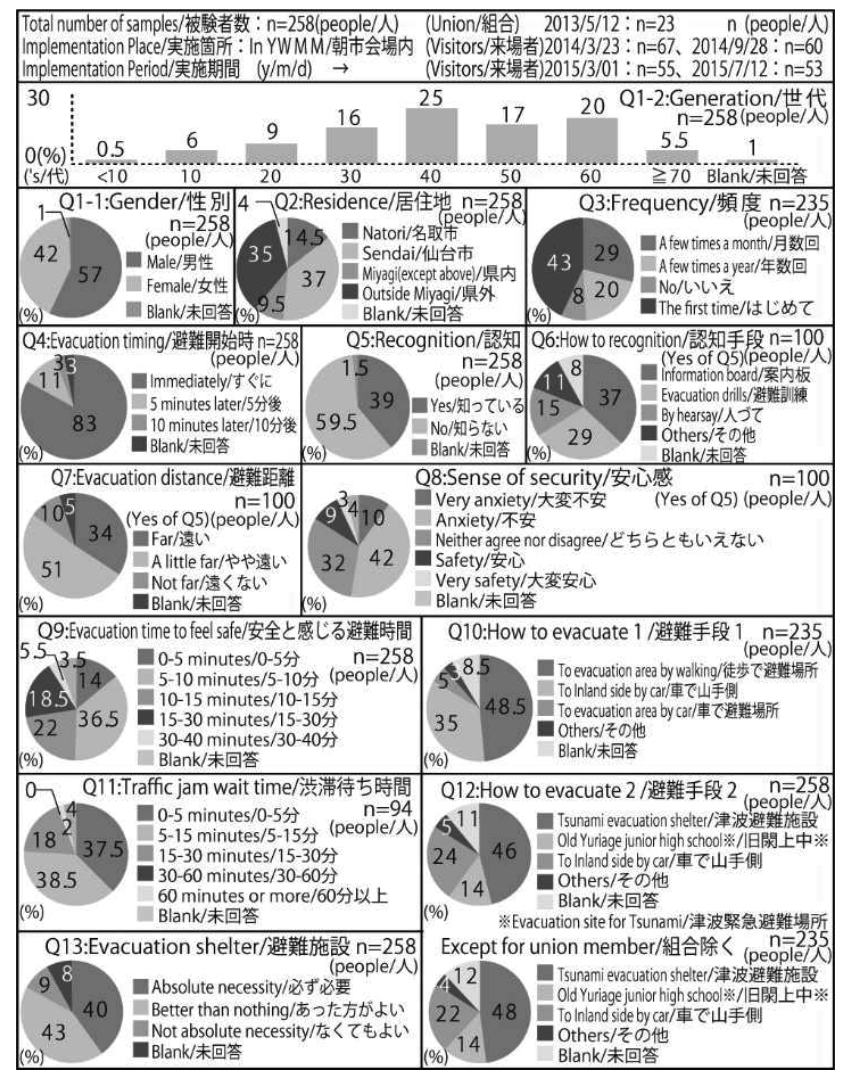

Fig. 6 Total results on union member and visitors in YWMM

\section{4-4. 朝市の避難空間の変遷}

朝市の避難空間の変遷を Photo 2、Fig.7、Fig.8 にまとめ、避難 空間がどう指定されたかを考察する。各図内の(1)～(5)は下記の避難 空間に対応する。

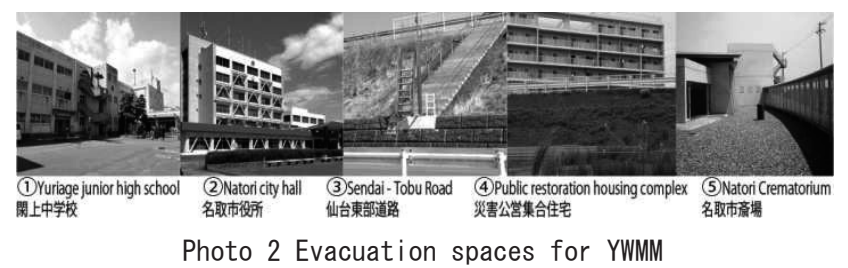




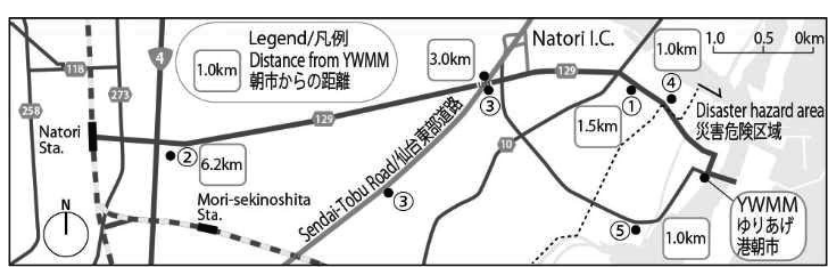

Fig. 7 Evacuation spaces for YWMM

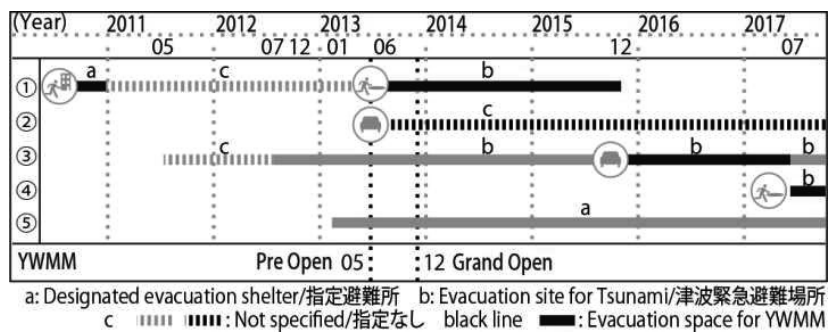

Fig. 8 Transition of Evacuation space for YWMM

本地区には指定避難所と避難場所が存在した。避難空間として名 取市指定のない時期もあり、仙台東部道路や未指定の名取市役所が 朝市の避難場所とされていた。盛土整備後に建設された避難場所の 災害公営集合住宅が最終の避難場所となった。

\section{(1) 闒上中学校 (指定避難所 $\rightarrow$ 震災後避難場所 $\rightarrow$ 解体)}

䦥上中学校は、 $\mathrm{RC}$ 造 3 階建て、1979 年に竣工し、震災以前は指 定避難所として名取市指定を受けていた。震災により被災し廃校と なった。現地に指定避難所の看板は残され、指定避難所の機能はな いが、2012 年 12 月の朝市のグランドオープン時には避難場所とし て看板が再整備された。屋上面積は概算で $800 \mathrm{~m}^{2}$ 程あり、津波避難 警報時には屋上に約 800 人の一時避難が想定される。注 10) その後 2015 年 12 月に闒上中学校の解体着手となった。

\section{(2) 名取市役所(指定なし)}

名取市役所は避難空間として名取市指定はされていなかった。朝 市の避難経路案内には徒歩の場合に闒上中、車・バスの場合に名取 市役所が明記されていた。朝市からは $6.2 \mathrm{~km}$ あり、徒歩で向える場 所ではないが、朝市と市の協議により他に指定できる施設がないた

め、避難経路案内に掲載される経緯があった。

（3) 仙台東部道路について（震災後増設 $\rightarrow$ 避難場所）

震災直後 2011 年 5 月、東日本高速道路株式会社（以降 NEXCO 東日本）により名取 IC 仙台若林 JCT 間に避難階段として仮設階段 を自主的に設置した。2012 年 7 月までに津波避難階段を NEXCO 東日本が仙台東部道路及び常磐自動車道に 13 か所、そのうち名取 市に 3 か所設置した。2013 年 4 月以降、地方公共団体等が実施主 体となって占有許可を得て津波避難階段を整備・管理することが可 能になった。構造物自体の管理以外の日常の点検・清掃、災害時の 避難誘導、避難訓練等は関係市町が行った。12)

\section{(4) 閔上中央第一団地（震災後新設 $\rightarrow$ 避難場所）}

2017 年 7 月盛土に 6 階建て災害公営集合住宅完成時、屋上が避 難場所に名取市指定され、朝市来場者も利用可能な避難場所となっ た。 4 棟竣工時、建築面積は $2,626 \mathrm{~m}^{2}$ であった。名取市は屋上面積 の 8 割、避難階段面積の 5 割、共用廊下の 4 割を有効面積とし、団 地内 4 棟で 2640 名程度と試算している。

\section{(5) 名取市斎場 (震災後復旧 $\rightarrow$ 指定避難所)}

名取市斎場[以下、斎場]は、朝市から約 $1.0 \mathrm{~km}$ の場所にある。被
災後、復旧工事で高さ $10 \mathrm{~m}$ の屋上へ新たに避難階段を設置し、被災 時に緊急避難できるよう整備された。延面積は $2,136 \mathrm{~m}^{2}$ で収容人数 は避難所として 50 人、避難場所として 500 人が想定された。災害 危険区域に現存する指定避難所だが、朝市から南に位置し海に対し 離れない避難移動となるため斎場は避難場所とはならなかった。

以上、朝市の避難空間の変遷を明らかにした。仙台東部道路のよ うに名取市指定前に自主的に整備された避難場所や、名取市指定さ れていない市役所が避難場所として明示されており、暫定的な避難 空間の設置がなされた。行政が堅牢な避難空間の建設に固執せず、 既存空間の活用により朝市に安全を提供した。避難空間の性能とし ては課題があったものの避難空間確保を優先することで、利用者や 近隣住民からの再建への批判もなく運営していることが分かった。

\section{4-5. 小結}

災害危険区域内かつ設計津波水位 L1 以下の土地に立地する朝市 は、様々な地域からの利用者の存在と利用者の寛容な避難意識によ り、現地再建当初から震災前相当の集客を確保していた。朝市来場 は利用者の判断に委対られるが、事業者として集客する立場のため 安全確保の責任がある。朝市に隣接する避難場所の建設には至って いないが、既存空間を活用した避難空間の持続的な確保を行政と共 に実現していた。近隣市街地や県外からの良好なアクセスによる自 動車来場する様々な利用者と、被災を受けた平地の中で限られた既 存空間を活用した避難空間によって、朝市は支えられ商業活動を持 続できていたことが分かった。

\section{5. まとめ}

以上、早期再建に関わる外的要因に対する組合の施策から得られ た事業復興に有効な知見をまとめる。

(1)事前の再建案検討と再建時期の予見 : 被災直後では再建時期は嵩 上げ等の公共事業、規制の設定によって再建できる機会は限られる。 再建できる機会が訪れた際に迅速に対応するために再建案の事前検 討を進め、行政動向を把握し再建時期が予見されていたことが明ら かとなった。早期再建後すぐに観光客入込数が被災前相当数を確保 しており、早期再建は事業復興に有効と考えられる。

(2)立地に即した避難対策と避難空間の指定 : 再建場所の安全性と危 険性、利用者動向を把握し、避難対策や暫定的な避難空間が確保さ れていたことが明らかとなった。現地再建を優先し危険性がある場 合も被災が大きいほど避難空間の確保は難しいが、既存空間を柔軟 に活用し避難空間を確保することは事業復興に有効と考えられる。 (3)支援者を引き込む端緒づくり：再建事業に適合した寄付金の取得 は重要であり、寄付金の中には少ない採択数で限られた範囲で情報 公開される事業も存在するため、行政や関連事業者との連携は有益 であることが明らかとなった。支援者が事業に関心を持つ既存用途 と共に、㮩いの場や防災発信拠点といった社会貢献につながる場の 創出が支援者を引き込み、事業復興に有効と考えられる。

\section{6. 展望}

本事例は危険性を伴う立地に存在するが、事業者、行政、利用者 の総意のもと、被災前と同じ場所で商業施設として最も早期に再建 した。被災前と遜色ない復興を実現し、社会貢献につながる場の創 出も試みられ、朝市の事業復興と共に地域の復興を先導する事業と 
いえる。今後未曾有の災害時にも、本事例等から得られる知見を研 究し、被災時に起こりうる状況を予見し的確な計画を進め、復興を 先導する事業が創出される方法論の基礎研究を実施していきたい。

\section{謝辞}

本研究は JSPS 科研費 25630254 の助成を受けたものです。

\section{参考文献}

1) Hizume, H., Nagano, S. and Yamada, S. : A Study on the recovery process and the regional contribution of Yuriage Wharf Morning Market after the Great East Japan Earthquake, Journal of Architecture and Planning (Transactions of AIJ), Vol.82, No.741, pp. 2865-2874, 2017. 11 (in Japanese)

日詰 博文, 永野 聡, 山田 俊亮: 東日本大震災におけるゆりあげ港朝市の復 興過程と地域貢献に関する研究, 日本建築学会計画系論文集, 第 82 巻 第 741 号, pp. 2865-2874, 2017. 11

2) Isoda, Y. and Nozawa, Y. : Influence on Shopping Street by Large Scale Reconstruction after the Tsunami, Journal of the City Planning Institute of Japan, Vol.52 No. 3, pp. 1066-1073, 2017.10(in Japanese) 磯田 芳枝, 野澤 康: 東日本大震災の津波被害における復興市街地整備事 業が商店街再建に及ぼした影響に関する一考察, 都市計画論文集, 第 52 巻 第 3 号, pp. 1066-1073，2017. 10

3) Matsumoto, E. and Ubaura, M. : A Study on Designation Disaster Hazard Areas after the Great East Japan Earthquake, Journal of the City Planning Institute of Japan, Vol.50 No.3, pp.1273-1280, 2015.10 (in Japanese)

松本 英里, 姥浦 道生：東日本大震災後の災害危険区域の指定に関寸る研 究，都市計画論文集 第 50 巻 第 3 号, pp. 1273-1280, 2015. 10

4) Nieda, J., Ubaura, M., Karaya, T. and Kochizawa, M. : A Study on Building Restrictions in Early Stage after the Great East Japan Earthquake and its Effect on Urban Form, Journal of the City Planning Institute of Japan, Vol. 53 No. 3, pp. 1199-1206, 2018.10 (in Japanese)

䞇田 純平, 姥浦 道生, 苅谷 智大, 小地沢 将之: 東日本大震災後の初動期 における建築規制とその空間形成への影響に関する研究, 都市計画論文集, 第 53 巻 第 3 号, pp. 1199-1206，2018. 10

5) Sakai, T. and Murao, 0. : Development Process of Post-tsunami Recovery plan after the 2011 Great East Japan Earthquake and Tsunami for Yuriage, Natori City, Reports of the City Planning Institute of Japan, No. 18, pp. 58-63, 2019.5 (in Japanese)

酒井 俊史, 村尾 修: 2011 年東日本大震災後の名取市闒上地区における震 災復興まちづくりの計画策定過程, 都市計画報告集, 第 18 号, pp. 58-63, 2019.5

6) Abe, T., Fujioka, M. and Sato, S. : Establishment of community development corporations at the local disaster reconstruction, Journal of Architecture and Planning(Transactions of AIJ), Vol82, No. 735 , pp. 1221-1230, 2017.5 (in Japanese)

阿部 俊彦, 藤原 諒, 佐藤 滋:復興まちづくりにおけるまちづくり会社の組 成プロセスに関する研究, 日本建築学会計画系論文集, 第 82 巻 第 735 号, pp. 1221-1230，2017.5

7) Nakajima, T. : Disaster Support Giving to March 11 Japan Earthquake Relief: With a Focus on Support Funds for Recovery, OSIPP Discussion Paper, No. J-007, 2014. 5 (in Japanese)

中嶋 貴子: 東日本大震災における災害寄付の実態と課題: 活動支援金を中 心に，OSIPP ディスカッションペーパー，第 J-007 号，2014.5

8) Nagano, S., Hizume, H. and Yamada, S. : Disaster Support Giving to March 11 Japan Earthquake Relief, Journal of Personal Finance, No. 3, pp. 47-54, 2016 (in Japanese)

永野 聡, 日詰 博文, 山田 俊亮: 東日本大震災における災害寄付の実態と 課題，パーソナルファイナンス研究，第 3 号，pp. 47-54， 2016

9) Ichiko, T. : A Discussion for self-active Tunami Evacuation in the Great East Japan Earthquake - Comparative analysis between Yamada Town and Ishinomaki City, Journal of Japan Association of Earthquake Engineering, Vol.15, No. 5, pp. 31-40, 2015 (in Japanese)

市古 太郎：東日本大震災における「主体的な津波避難」に関寸る考察-山 田町・旧石巻市域での比較分析-, 日本地震工学会論文集, 第 15 巻、第 5 号, pp. 31-40, 2015

10) Murakami, H. : A study on Fatality and Factors Affecting Evacuation
Delay in Natori City Hit by the 2011 Great East Japan Earthquake and Tsunami -Analysis of Damage Statistics and Tsunami Evacuation Questionnaire Data-, Journal of social safety science, No. 24, pp. 101-110, 2014.11 (in Japanese)

村上 ひとみ：2011 年東日本大震災による名取市の人的被害と避難遅れ影 響要因-被害統計と津波避難アンケートの分析-，地域安全学会論文集，第 24 号, pp. 101-110, 2014. 11

11) The Nippon Foundation: Report of Road Project -Activity record for first (second and third) year after the Great East Japan Earthquake- , The Nippon Foundation, 2012.06 (in Japanese) 日本財団：ROAD プロジェクト東日本大震災 $1(2,3)$ 年間の活動記録，日本財 団, 2012.06

12) Tohoku region's Administrative Evaluation Bureau of Ministry of Internal Affairs and Communications: Administrative evaluation and surveillance on ensuring road safety and convenience, Ministry of Internal Affairs and Communications, 2014.3(in Japanese) 総務省東北管区行政評価局: 道路の安全及び利便の確保に関する行政評 価・監視結果報告書, 総務省, 2014.3

13 ) Miyagi prefecture tsunami countermeasure guideline, Miyagi prefecture tsunami countermeasure contact council,2017.10(in Japanese)

宮城県津波対策ガイドライン, 宮城県津波対策連絡協議会, 2017.10

\section{注}

注 1）震災直後 2011 年 10 月名取市震災復興計画にて、本敷地が含まれる「貞 山運河東側の土地利用は基本的に非居住」と明記された。この時点で法 ・ 条例の指定はなく、その後 2013 年 12 月災害危険区域に追加指定された。

注 2) 名取市が活用している用語を使用している。指定避難所における二次 避難所や、緊急避難場所における一時避難場所、広域避難場所の細分の明 記はない。アンケート時、津波避難施設と記載したが、本研究における津 波緊急避難場所 (避難場所) と同義である。

注 3）(1)「立地」が震災後、災害危険区域等の規制を受け、規制の施行後に 再建となると「再建時期」は遅れる。(2)「立地」の被苂状況や計画策定状 況により、既存敷地で再建できない場合、新しい敷地の確保のために関係 機関と調整が必要となる。嵩上地であれば、造成工事後の再建となるため 「再建時期」は遅れる。(3)「立地」の安全性確保と避難対策の調整を実施す るにあたり、専門家、行政、住民の判断が厳格か、寛容かで整備基準は変 わる。特に厳格であれば、関係機関との調整に時間を要し「再建時期」は 遅れる。(4)「立地」の避難空間の有無で、新設する場合は、竣工まで既存 施設整備で避難空間を確保できなければ「再建時期」は遅れる。自己資金 で避難空間を確保することで解決可能ではあるが「建設資金」次第となる。 (5)本体施設の「建設資金」確保は、自己資金で賄えない場合、外部資金に 頼る必要がある。外部資金の申請時には「再建時期」や「立地」の目途が 関係機関との調整の上、完了しておく必要がある。公的資金を利用する場 合、造成工事が優先されるため「再建時期」は遅れる。

注 4）筆者らは、朝市のマネジメントを担う株式会社プラットホーム閖上を 設立し、施設再建前から建築・都市計画分野の専門性を活かし、再建への 支援と避難対策の検討を実施してきた。

注 5) 日本財団は助成機関・中間支援組織として多額の寄付金 (2011 年度 58 億円) を様々な組織への活動支援配分しており比較対象とした。

注 6）「東日本大震災による被災現況調査結果について（第 1 次報告）国土 交通省, 2011.08, 名取市: 水深と建物被災状況の関係、用途地域と建物被 災区域の重衫合わせ図(国交省 HP, http://www.mlit.go.jp/toshi/city_plan/ crd_city_plan_tk_000005.html, 2016.05.01閲覧)」より、閖上地区の貞山 掘東側は、A区域「建造物の多くが全壊（流失）、全壊、全壊（1階天井以 上浸水）の区域」に $90 \%$ 以上が該当している。

注 7) 慰霊碑は、2014 年 8 月 11 日に名取市により設置された。碑文とあわせ、 震災により犠牲になられた 944 名の方の御芳名が記されている。

注 8）日和山は、標高 $6.3 \mathrm{~m}$ の築山。震災後、闒上地区一帯を見渡せ、多くの 人が訪れ、鎮魂の場となっている。

注 9）宮城県津波対策ガイドライン ${ }^{13)}$ によると、徒歩避難速度は， $1.0 \mathrm{~m} /$ 秒が 目安、避難の限界距離は $500 \mathrm{~m}$ が目安とされる。社会福祉施設、病院等、高 齢者等への配慮が必要な施設がある場合は、さらに歩行速度が低下 $(0.5 \mathrm{~m} /$ 秒）することを考慮、自動車による避難速度は，3.0 m/秒とされている。 注 10）宮城県津波対策ガイドライン ${ }^{13)}$ によると、避難者 1 人当たり十分なス ペースを確保すること（最低限 1 人当たり $1 \mathrm{~m}^{2}$ 以上）とされている。 


\title{
A STUDY ON EXTERNAL FACTORS AND MEASURES RELATED TO THE EARLY RECONSTRUCTION OF YURIAGE WHARF MORNING MARKET AFTER THE GREAT EAST JAPAN EARTHQUAKE
}

- Project comparison of similar coastal commercial facilities and tsunami evacuation in the morning market -

\author{
Hirofumi HIZUME ${ }^{* 1}$, Satoshi NAGANO ${ }^{* 2}$ and Shunsuke YAMADA*3 \\ ${ }^{* 1}$ Shoichi Haryu Architect and Associates, M.Arch. \\ *2 Assoc. Prof., College of Social Sciences, Ritsumeikan University, Dr.Arch. \\ *3 Assist. Prof., Faculty of Human Ecology, Yasuda Women's Univ., M.Eng.
}

This study examines the external factors involved in the early reconstruction of the Yuriage Wharf Morning Market (YWMM) and the measures taken by the union to respond to these external factors. The purpose of this study is to identify effective knowledge for business recovery through early reconstruction.

In Chapter 3, we identify the measures taken by the union in response to external factors. This study compares similar coastal commercial facilities after the Great East Japan Earthquake in terms of external factors such as Reconstruction period, Location, and Construction funds. "Reconstruction period" was categorized by confirming public works and evacuation measures until the facilities opened. "Location" compared ground level, relationship to the disaster risk zone, and distance to the town hall and the sea. The "Construction funds" reviewed the construction costs and history of donations.

In Chapter 4, in order to clarify the tsunami evacuation situation in the morning market, the internal factor of the union's evacuation measures is organized. It then considers the external factors related to location: users and evacuation space. In order to determine the attributes of the users and their evacuation attitudes, a survey was conducted in YWMM. And in order to identify the evacuation spaces in the morning market, the location and outline of each evacuation space was compiled through administrative documents and field surveys.

Summarize the findings from the union's measures for external factors related to early reconstruction that are useful for business recovery.

1. Consideration of preliminary reconstruction plans and prediction of the reconstruction period.

After the early reconstruction, the number of tourists immediately reached the same level as before the disaster, and the early reconstruction is considered to be effective for the reconstruction of the business.

2. Evacuation measures and designation of evacuation space in response to the location.

If there is a risk by prioritizing rebuilding in the original location, it is difficult to secure a sustainable evacuation space if the damage is significant, but flexible use of existing space to secure an evacuation space may be effective for project reconstruction.

3. Creating Opportunities to Engage Supporters.

In addition to the existing uses that supporters are interested in, the creation of places that will contribute to society, such as relaxation areas and disaster prevention centers, will be effective in attracting supporters to the project and its recovery.

This case exists in a risky location, but with the consensus of the business, the government and the users, it was the earliest commercial facility to be rebuilt in its original location before the disaster. This project was on the same level as the one before the disaster, and it was also an attempt to create a place to contribute to society, and it can be said that it was a project that led the way to the reconstruction of the region as well as the reconstruction of the morning market. 